\title{
KERATOKONUSTA KORNEA ENDOTEL HÜCRE ÖZELLIKLERININ TOPOGRAFİK EKTAZİ GÖSTERGELERİ İLE KARŞILAŞTIRILMASI
}

\author{
The Comparison of Corneal Endothelial Cell Properties with the Topographic Ectasia Indexes \\ in Keratoconus
}
Nesrin BÜYÜKTORTOP GÖKÇINAR ${ }^{1}$, Yaprak AKBULUT ${ }^{2}$, Tevfik OĞUREL ${ }^{3}$, Salih KOÇ ${ }^{4}$, Zafer ONARAN ${ }^{5}$

1,2,3,4,5 Kırlkkale Üniversitesi Tıp Fakültesi, Göz Hastalıkları Anabilim Dalı, KIRIKKALE, TÜRKİYE

Amaç: Keratokonuslu gözlerde kornea endotel hücre özellklerini incelemek ve topografik keratokonus tarama indeksleri ile korelasyonunu araştırmak.

Gereç ve Yöntemler: $\mathrm{Bu}$ prospektif çalışmada keratokonus hastalarında ve sağlıklı gözlerde kombine Scheimpflug-Placido disk kornea topografi cihazı (CSO Sirius, Floransa, İtalya) ile ön yüzey apikal kurvatür, en ince kornea kalınlığı (EIKKK), simetri indeksi, keratokonus verteksi ve Baiocchi-Calossi-Versaci (BCV) indeksi adı verilen keratokonus tarama indeksleri kaydedildi. Kornea endoteli temassız speküler mikroskopi cihazı (Konan Cell Check SL, Hyogo, Japonya) ile incelendi. Endotel hücre yoğunluğu (EHY), hücre alanlarının değişkenlik katsayısı (DK) ve altıgen hücre yüzdesi (AHY) kaydedildi. Keratokonus tarama indeksleri ve endotel hücre özellikleri keratokonuslu gözler ve sağlıklı gözler arasında karşılaştırıldı. Topografik indeksler ile endotel hücre özellikleri arasındaki korelasyon incelendi.

Bulgular: Çalışmamızda keratokonus grubunda 45 keratokonus hastasının 70 gözü ile kontrol grubunda 50 sağlıklı gönüllünün 50 gözü bulunmaktaydı. Hastalık şiddetine göre 24 göz hafif, 36 göz orta, 10 göz ileri keratokonus grubuna alındı. Keratokonus grubunda DK kontrol grubuna göre anlamlı olarak yüksekti $(p=0.015)$. Ortalama EHY ve AHY ise kontrol grubundan düşüktü, ancak bu fark istatistiksel olarak anlamlı değildi. Keratokonus evreleri arasında endotel hücre özellikleri açısından anlamlı fark saptanmadı $(p>0.05)$. EİKK ile EHY arasında zayıf ama anlamlı korelasyon saptand1 $(r=0.231$; $p=0.011$ ). DK ile keratokonus tarama indekslerinin büyük kısmı ve apikal kurvatür arasında zayıf ama anlamlı korelasyon olduğu izlendi $(r=\sim 0,2 ; p<0.05)$.

Sonuç: Keratokonusta endotel hücre alan varyasyonu artmaktadır. $\mathrm{Bu}$ artış topografik keratokonus tarama indeksleri ve apikal kurvatür ile koreledir. Kornea endotel hücre özelliklerinin keratokonus şiddeti ile beraber değişebildiği göz önünde bulundurulmalıdır

Anahtar Kelimeler: Keratokonus, kornea topografisi, kornea endotel hücre yoğunluğu, speküler mikroskopi
Objective: To investigate the corneal endothelial cell characteristics in eyes with keratoconus and to analyze their correlation with topographic keratoconus screening indices.

Material and Methods: In this prospective study, apical curvature and keratoconus screening indexes including thinnest corneal thickness (TCT), symmetry index, keratoconus vertex, and Baiocchi-Calossi-Versaci index were recorded in keratoconus patients and healthy eyes using a combined Scheimpflug-Placido disc corneal topography device (CSO Sirius, Florence, Italy). Corneal endothelium was examined with non-contact specular microscopy device (Konan Cell Check SL, Hyogo, Japan). The endothelial cell density (ECD), coefficient of variation of cell areas (CV) and percentage of hexagonal cells (HEX) were recorded. The keratoconus screening indexes and endothelial cell properties were compared between the keratoconic and healthy eyes. The correlation between topographic indexes and endothelial cell properties was evaluated.

Results: In our study, there were 70 eyes of 45 keratoconus patients in the keratoconus group and 50 eyes of 50 healthy volunteers in the control group. Twenty-four eyes were recruited to mild, 36 eyes to medium, and 10 eyes to advanced to keratoconus groups according to the severity of disease. In keratoconus group $\mathrm{CV}$ was significantly higher than in the control group $(p=0.015)$. Mean ECD and HEX were also lower than the control group, but this difference was not statistically significant. No significant difference was found between the stages of keratoconus in terms of endothelial cell characteristics $(p>0.05)$. A weak but significant correlation was found between TCT and ECD $(r=0.231 ; p=0.011)$. There was a weak but significant correlation between $\mathrm{CV}$ and most of the keratoconus screening indexes and apical curvature $(r=\sim 0.2 ; p<0.05)$.

Conclusion: Endothelial cell area variation increases in keratoconus. This increase is correlated with topographic keratoconus screening indexes and apical curvature. It should be kept in mind that corneal endothelial cell characteristics may change with the severity of keratoconus.

Keywords: Corneal topography, corneal endothelial cell density, keratoconus, specular microscopy

Dr. Nesrin Büyüktortop GÖKÇINAR

Yazışma Adresi / Correspondence:

Kırıkale Üniversitesi Tıp Fakültesi, Göz Hastalıkları Anabilim Dalı, KIRIKKALE, TÜRKIYYE
Tel / Phone: +905332307412
E-posta / E-mail: tortopn@kku.edu.tr

Geliș Tarihi / Received: 19.04.2019

${ }^{1} 0000-0001-7795-5188,{ }^{2} 0000-0002-7774-2681$

Kabul Tarihi / Accepted: 10.08.2019

${ }^{3} 0000-0003-0658-2286,{ }^{4} 0000-0001-8700-2938$ 


\section{GíRiş}

Keratokonus korneanın incelmesi, protrüzyonu ve konik şekil alması ile karakterize etiyolojisi tam olarak bilinmeyen bir kornea ektazisidir (1). Genellikle bilateraldir, ancak asimetrik seyretmektedir. Prevalansı populasyonun coğrafik ve etnik özellikler ile tanı kriterlerine göre değişkenlik göstermekle birlikte sıklıkla 100.000 'de 50 ila 230 aralığında bildirilmektedir (1). Tipik özelliği puberte döneminde başlayarak ilerleyen miyopi, irregüler astigmatizma ve görme azlığıdır (2). Keratokonus erken tanı ve takibinde korneanın topografik ve tomografik analizini yapabilen cihazlar çok değerlidir (3). Bu cihazlar Scheimpflug kamera, tarayıcı slit ve Placido disk sistemlerini kullanmaktadır. Topografi cihazlarının yazılımlarında özgün ektazi indeksleri bulunmaktadır; bu indeksler hastalık tanısı ve takibinde algoritma desteği sağlamaktadırlar (4).

Keratokonus hastalığı hem ön hem de arka korneal yüzeyi etkileyen ektatik bir hastalık olduğundan kornea endotel hücre sayısında ve morfolojisinde değişiklikler olabileceği ileri sürülmektedir (5). Bu hipotezi destekleyecek şekilde kornea nakli esnasında keratokonuslu gözlerden çıkarılan kornea dokularının histopatolojik incelemesinde endotel hücre morfolojisinde bozulma olduğunu gösterilmiştir (6). Ancak, keratokonusta endotelin ne derece etkilendiği konusu henüz netlik kazanmamıştır. Literatürde bu alanda farklı sonuçlar bildiren çalışmalar mevcuttur (513). Konfokal mikroskopi ve speküler mikroskopi ile yapılmış araştırmalarda endotel hücre yoğunluğunun azaldığı, değişmediği veya arttığı yönünde sonuçlar bulunmaktadir (7-13).

Speküler mikroskopi cihazları ile kornea endotel hücrelerini kantitatif, kalitatif ve morfometrik olarak değerlendirmek mümkündür; endotel hücre yoğunluğu, hekzagonalite, değişkenlik katsayısı, kornea kalınlığı, hücre alanı analiz edilebilmektedir (14).
Çalışmamızda speküler mikroskopiyi kullanarak keratokonuslu gözler ile sağlıklı gözlerin kornea endotel özelliklerini karşılaştırmak ve keratokonusta endotel hücre yoğunluğunda ve hücre morfolojisinde değişiklik olup olmadığını araştırmayı hedefledik. Ayrıca, keratokonus grubunda gözleri klinik şiddete göre gruplandırarak endotel hücre özellikleri ile hastalık şiddeti arasında ilişki olup olmadığını değerlendirmek istedik. Çalışmadaki diğer hedefimiz kombine Scheimpflug kamera Placido disk sistemi ile çalışan kornea topografi cihazının keratokonus tarama indeksleri ile kornea endotel özellikleri arasındaki korelasyonu araştırmaktı.

\section{MATERYAL VE METOD}

Çalışma Kırıkkale Üniversitesi Klinik Araştırmalar Etik Kurulu (Tarih, say1; 2019-09/01) onayıyla Helsinki Deklarasyonu'na uygun şekilde yürütüldü. Tüm katılımcılardan aydınlatılmış onam alındı. Çalışmaya Kırıkkale Üniversitesi Tıp Fakültesi Göz Hastalıkları polikliniğine başvuran 45 keratokonus hastasının 70 keratokonuslu gözü ve 50 sağlıklı gönüllünün randomize 50 gözü dahil edildi. Keratokonus tanısı klinik bulgular ve topografik özellikler değerlendirilerek konuldu. Retinoskopide düzensiz makaslama reflesi, Vogt çizgileri, Fleischer halkası, Munson işareti, apikal incelme ve apikal skar gibi klinik muayene bulgularından en az biri ile beraberinde asimetrik papyon görünümü, parasantral dikleşme, inferior-superior asimetrisi gibi keratokonus ile uyumlu bir kornea topografi bulgusu olan gözler keratokonus grubuna alındı $(1,5)$. Keratokonusu veya başka bir göz hastalığı olmayan, sferik eşdeğer kırma kusuru 2 diyoptrinin (D) altında olan olgular kontrol grubuna dahil edildi. Çalışmadan dışlanma kriterleri yoğun kornea skarı, yeterli çekim kalitesi elde edilememesi, glokom, diabetes mellitus, son 1 yıl içerisinde kontakt lens kullanma, korneal çapraz bağlama veya cerrahi hikayesi idi. Keratokonus şiddeti 
Amsler-Krumeich sinıflamasına göre değerlendirildi (1). Evre-1 gözler hafif keratokonus, evre-2 gözler orta düzey keratokonus, evre-3 ve evre-4 gözler ileri keratokonus olarak gruplandırıldı.

\section{Kornea Topografi Cihazı ile Inceleme}

Olguların kornea topografik incelemeleri kombine Scheimpflug kamera-Placido disk sistemli ön segment analiz cihazı (Sirius, CSO, Florensa, İtalya) ile yapıldı. Sirius cihazı korneanın ön yüzey bilgisini Placido ve Scheimpflug sistemlerinin verilerini birleştirerek, kornea arka yüzey, lens ön yüzeyi ve iris verilerini ise Scheimpflug kameradan elde etmektedir. Cihazın yazılım sistemi (Phoenix v.3.0.1.021, bon Optic Vertriebs GmbH, Lübeck, Almanya) destek vektör makinesi adı verilen bir makine öğrenimi sınıflayıcısı ile gözü, normal, keratokonus, keratokonus şüphesi, miyopi nedeniyle refraktif cerrahi geçirmiş veya anormal/ tedavi uygulanmış olarak sınıflamaktadır. Destek vektör makinesi algoritma sisteminin kullandığ1 keratokonus tarama indeksleri şunlardır: 1) Ön yüzey kurvatür haritasında simetri endeksi (SIf): Vertikal eksende inferior yarımkürede merkezi $[x=0 \mathrm{~mm}, \mathrm{y}=$ $1,5 \mathrm{~mm}$ ] koordinatlarında yer alan ve yarıçapı $1,5 \mathrm{~mm}$ olan dairesel alanın superior yarımküredeki simetriği arasındaki ortalama anterior yüzey tanjansiyel kurvatür farkı, 2) Arka yüzey kurvatür haritasında simetri endeksi (SIb): SIf indeksinin arka yüzeydeki eşdeğeri, 3) Ön keratokonus verteksi (KVf): Ön yüzeyde ektazinin en yüksek noktası, 4) Arka keratokonus verteksi (KVb): Arka yüzeyde ektazinin en yüksek noktası, 5) En ince kornea kalınlığı (EİKK), 6) Baiocchi-Calossi-Versaci indeksi (BCV): Koma, trefoil ve sferik aberasyonun karekök değerlerinin ektazi aksının fonksiyonu ile dengelendiği bir formüldür. Ön yüzey BCV (BCVf) ve arka yüzey BCV (BCVb) indekslerinin vektöryel toplamıdır.

Çalışmamızda olguların Sirius cihazı ile elde edilen ve yukarıda bahsedilen keratokokonus tarama indeksi ölçümleri yanı sıra, progresyon analizinde sıklıkla kullanılan apikal kurvatür (AKf, maksimum keratometri, ön yüzey apikal keratoskopi) ölçümleri kaydedildi (2).

Speküler Mikroskopi ile Endotel Hücre Özelliklerinin Incelenmesi

Olguların kornea endotel özellikleri temassız speküler mikroskopi (Konan Cell Check SL, Konan Medical Inc, Hyogo, Japonya) ile incelendi. CellCheck SL cihazı iki farklı refraktif indeksli ortama ait düzgün bir ara yüzeyde gelen ışığın açısına eşit açıda yansıma ile oluşan speküler refle prensibi ile çalışmaktadır (14). Çalışmamızda cihazın otomatik hizalama ve otomatik odaklama özelliği ile merkezi korneadan alınan kesitler üzerinde "merkez (center) metodu" ile hücre sayımı yapıld1. En az 70, ortalama 141.02 \pm 23.33 hücre sayıldı. Endotel hücre yoğunluğu (EHY, hücre sayısı/ $/ \mathrm{mm}^{2}$ ), hücre alanlarının değişkenlik katsayısı (DK, polimegatizm, \%) ve altıgen hücre yüzdesini ifade eden hekzagonalite (AHY, \%) kaydedildi.

\section{Istatistiksel Analiz}

İstatistiksel analiz SPSS 21.0 paket programı (IBM SPSS Statistics for Windows, sürüm 21.0. Armonk, NY: IBM Corp.) kullanılarak yapıldı. Verilerin normal dağılıma uyup uymadığı Kolmogorov-Smirnov testi ile değerlendirildi. Sonuçlar ortalama \pm standart deviasyon ve aralık olarak verildi. Kategorik değişkenler ki-kare testi ile incelendi. Sayısal değişkenler keratokonus ve kontrol grubu arasında normal dağılıma uygunluğa göre bağımsız örneklem t-testi veya Mann Whitney U testi ile karşılaştırıldı. Hafif, orta ve ileri keratokonuslu gözler arası karşılaştırmalar normal dağılıma uygunluğa göre tek yönlü varyans analizi (ANOVA) veya Kruskal-Wallis testi ve anlamlılık durumunda ikili karşılaştırmalar Bonferroni düzeltmesi ile incelendi. Endotel hücre özellikleri ile keratokonus tarama indeksleri arasındaki korelasyon normal dağılıma uygunluğa göre Pearson veya Spearman korelasyon testi ile incelendi. $p<0,05$ anlamlı kabul edildi. 


\section{BULGULAR}

\section{Demografik Özellikler}

Çalışmaya 45 keratokonus hastasının 70 gözü ile 50 sağlıklı gönüllünün 50 gözü dahil edildi. Olguların yaş ortalamas1 keratokonus grubunda 31.06 \pm 9.64 (17-56); kontrol grubunda $29.76 \pm 8.40$ (18-53) idi. Kadın / erkek oran1 keratokonus grubunda 20/25; kontrol grubunda 25/25 idi. İki grup arasında yaş ve cinsiyet açısından anlamlı fark yoktu (sırasıyla $p=0.607$ Mann Whitney-U testi, $p=0.588 \chi^{2}$ testi). Sağ göz / sol göz oranı keratokonus grubunda 33/37; kontrol grubunda 23/27 idi. Çalışmada yer alan göz tarafı açısından da gruplar arasında anlamlı fark yoktu ( $p=0.902 \chi^{2}$ testi). Amsler Krumeich sınıflamasına göre evre 1 gözler $(n=24)$ hafif keratokonus, evre 2 gözler $(\mathrm{n}=36)$ orta şiddette keratokonus, evre $3(n=8)$ ve evre $4(n=2)$ gözler ileri keratokonus olarak kabul edildi.

\section{Endotel Hücre Verileri}

Keratokonus grubunda ortalama EHY ve AHY kontrol grubundan düşük olmakla birlikte bu fark istatistiksel olarak anlamlı değildi. DK keratokonus grubunda kontrol grubuna göre anlamlı olarak yüksekti $(p=0.015)$ (Tablo 1).

Keratokonuslu gözler Amsler Krumeich sinıflamasına göre klinik olarak hastalı şiddeti açısından gruplandığında gruplar arasında endotel hücre özellikleri açısından anlamlı fark saptanmadı $(p>0.05)$

(Tablo 2).

\section{Topografik Veriler}

Kombine Scheimpflug kamera Placido disk sistemli ön segment analiz sisteminin özgün keratokonus tarama indeksi ve apikal kurvatür verileri keratokonus evreleri arasında karşılaştırıldığında evreler arasında anlamlı fark olduğu görüldü (hepsi $p<0,05$ ). En ince kornea kalınlığının ileri keratokonus grubunda hafif ve orta evrelere göre anlamlı olarak daha ince olduğu; diğer parametrelerin özellikle hafif ve orta keratokonus grupları arasında anlamlı farklı olduğu; elevasyon indeksleri, BCV ve apikal kurvatürün ayrıca hafif ve ileri keratokonus grupları arasındaki karşılaştırmalarda anlamlı farklı olduğu izlendi (Tablo 3).

Tablo 1: Keratokonus ve kontrol grubunda speküler mikroskopi ile endotel hücre özellikleri

\begin{tabular}{lccc}
\hline Parametre & Keratokonus Grubu $(\mathbf{n = 7 0})$ & Kontrol Grubu $(\mathbf{n = 5 0})$ & $\boldsymbol{p}$ değeri \\
\hline EHY (hücre $/ \mathrm{mm}^{2)}$ & $2839.13 \pm 268.18$ & $2914.06 \pm 180.24$ & $0.07^{\alpha}$ \\
DK (\%) & $31.93 \pm 6 ., 63$ & $29.00 \pm 3.59$ & $0.015^{\beta}$ \\
AHY (\%) & $47.74 \pm 7.59$ & $49.00 \pm 6.98$ & $0.357^{\alpha}$
\end{tabular}

${ }^{\alpha}$ Bağımsız örneklem t-testi; ${ }^{\beta}$ Mann Whitney U testi. EHY: Endotel hücre yoğunluğu; DK: Endotel hücre alanı değişkenlik katsayısı; AHY: Altıgen hücre yüzdesi.

Tablo 2: Keratokonus şiddetine göre speküler mikroskopi ile endotel hücre özellikleri

\begin{tabular}{lcccc}
\hline Parametre & $\begin{array}{c}\text { Hafif Keratokonus } \\
(\mathbf{n = 2 4})\end{array}$ & $\begin{array}{c}\text { Orta Keratokonus } \\
(\mathbf{n = 3 6})\end{array}$ & $\begin{array}{c}\text { İleri Keratokonus } \\
(\mathbf{n = 1 0})\end{array}$ & $p$ değeri \\
\hline EHY (hücre/mm $\mathrm{mm}^{2)}$ & $2870.21 \pm 290.85$ & $2847.67 \pm 245.32$ & $2733.80 \pm 293.21$ & $0.392^{\alpha}$ \\
DK $(\%)$ & $31.29 \pm 7.71$ & $31.83 \pm 5.86$ & $33.80 \pm 6.81$ & $0.543^{\beta}$ \\
AHY (\%) & $48.67 \pm 7.87$ & $48.03 \pm 7.33$ & $44.50 \pm 7.71^{\beta}$ & $0.331^{\alpha}$ \\
\hline
\end{tabular}

${ }^{\alpha}$ Tek yönlü varyans analizi ANOVA testi; ${ }^{\beta}$ Kruskal-Wallis testi. EHY: Endotel hücre yoğunluğu; DK: Endotel hücre alanı değişkenlik katsayısı; AHY: Altıgen hücre yüzdesi. 
Tablo 3: Keratokonus şiddetine göre topografik keratokonus tarama indeksi ve apikal kurvatür verileri

\begin{tabular}{|c|c|c|c|c|c|}
\hline Parametre & $\begin{array}{l}\text { Hafif Keratokonus } \\
\qquad(n=24)\end{array}$ & $\begin{array}{l}\text { Orta Keratokonus } \\
\qquad(n=36)\end{array}$ & $\begin{array}{l}\text { İleri Keratokonus } \\
\qquad(\mathbf{n = 1 0})\end{array}$ & $\begin{array}{c}p \\
\text { değeri }\end{array}$ & $\begin{array}{c}p \\
\text { değeri* }\end{array}$ \\
\hline EİKK $(\mu \mathrm{m})$ & $499.21 \pm 25.12$ & $452.72 \pm 21.58$ & $401.80 \pm 29.69$ & $<0.001^{\alpha}$ & $<0.001^{\mathrm{a}, \mathrm{b}, \mathrm{c}}$ \\
\hline SIf (D) & $3.65 \pm 3.72$ & $5.58 \pm 2.64$ & $4.35 \pm 2.51$ & $0.002^{\beta}$ & $0.001^{\mathrm{a}}$ \\
\hline $\mathrm{SIb}(\mathrm{D})$ & $1.12 \pm 0.82$ & $1.55 \pm 0.68$ & $1.16 \pm 0.50$ & $0.004^{\beta}$ & $0.003^{\mathrm{a}}$ \\
\hline \multirow[t]{2}{*}{$\mathrm{KVf}(\mu \mathrm{m})$} & $20.54 \pm 15.25$ & $26.83 \pm 11.18$ & $31.70 \pm 13.70$ & $0.007^{\beta}$ & $0.027^{\mathrm{a}}$ \\
\hline & & & & & $0.023^{\mathrm{b}}$ \\
\hline \multirow[t]{2}{*}{$\mathrm{KVb}(\mu \mathrm{m})$} & $46.00 \pm 25.99$ & $65.72 \pm 24.35$ & $72.50 \pm 17.66$ & $0.001^{\beta}$ & $0.007^{\mathrm{a}}$ \\
\hline & & & & & $0.005^{\mathrm{b}}$ \\
\hline \multirow[t]{2}{*}{$\mathrm{BCV}$ (D) } & $2.17 \pm 1.43$ & $3.02 \pm 1,30$ & $3.08 \pm 1.11$ & $0.002^{\beta}$ & $0.003^{\mathrm{a}}$ \\
\hline & & & & & $0.045^{\mathrm{b}}$ \\
\hline BCVf (D) & $2.21 \pm 1.82$ & $2.88 \pm 1.29$ & $3.23 \pm 1.33$ & $0.012^{\beta}$ & $0.023^{\mathrm{a}}$ \\
\hline $\mathrm{BVCb}(\mathrm{D})$ & $2.33 \pm 1.50$ & $3.19 \pm 1.39$ & $3.05 \pm 0.86$ & $0.011^{\beta}$ & $0.018^{\mathrm{a}}$ \\
\hline \multirow[t]{2}{*}{ AKf (D) } & $51.42 \pm 5.50$ & $55.32 \pm 4.89$ & $56.56 \pm 5.27$ & $0.04^{\beta}$ & $0.011^{\mathrm{a}}$ \\
\hline & & & & & $0.018^{b}$ \\
\hline
\end{tabular}

* İkili karşılaştırmalar Bonferonni post hoc düzeltmesi ile elde edilen anlamlı $\mathrm{p}$ değerleri; ${ }^{\alpha}$ Tek yönlü varyans analizi ANOVA testi; ${ }^{\beta}$ Kruskal-Wallis testi; ${ }^{a}$ Hafif ve orta evre keratokonus grubu arasındaki karşılaştırmaya ait $p$ değeri; ${ }^{b}$ Hafif ve ileri evre keratokonus grubu arasındaki karşılaştırmaya ait p değeri; ${ }^{c}$ Orta ve ileri evre keratokonus grubu arasındaki karşılaştırmaya ait p değeri. EİKK: En ince kornea kalınlığı; SIf: Ön yüzey simetri indeksi; SIb: Arka yüzey simetri indeksi; KVf: Ön yüzey keratokonus verteksi; KVb: Arka yüzey keratokonus verteksi; BCV: Baiocchi-CalossiVersaci indeksi; BCVf: Ön yüzey BCV; BCVb: Arka yüzey BCV; AKf: Apikal kurvatür, maksimum keratometri.

Tablo 4: Endotel hücre özellikleri ile topografik indeksler arasındaki anlamlı korelasyonlar

\begin{tabular}{l|l|l}
\hline Parametre & $\boldsymbol{r}$ katsayısı & $\boldsymbol{p}$ değeri \\
\hline Değişkenlik katsayısı ile & 0.213 & $0.020^{\alpha}$ \\
SIf & 0.204 & $0.025^{\alpha}$ \\
$\mathrm{KVf}$ & 0.191 & $0.037^{\alpha}$ \\
$\mathrm{KVb}$ & 0.197 & $0.031^{\alpha}$ \\
$\mathrm{BCV}$ & 0.207 & $0.023^{\alpha}$ \\
$\mathrm{BCVf}$ & 0.184 & $0.044^{\alpha}$ \\
$\mathrm{BCVb}$ & 0.233 & $0.010^{\alpha}$ \\
$\mathrm{AKf}$ & 0.231 & $0.011^{\beta}$ \\
\hline Endotel hücre yoğunluğu ile & \multicolumn{2}{|}{} \\
EIKKK & \multicolumn{2}{|c}{} \\
\hline
\end{tabular}

${ }^{\alpha}$ Spearman korelasyon testi; ${ }^{\beta}$ Pearson korelasyon testi;

SIf: Ön yüzey simetri indeksi; KVf: Ön yüzey keratokonus verteksi; KVb: Arka yüzey keratokonus verteksi; BCV: Baiocchi-Calossi-Versaci indeksi; BCVf: Ön yüzey BCV; BCVb: Arka yüzey BCV; AKf: Apikal kurvatür, maksimum keratometri; EIKKK: En ince kornea kalınlığı.

Topografik Veriler ile Endotel Hücre Verilerinin Korelasyonu

Keratokonus tarama indekslerinin hastalık şiddeti ile ilgili olması nedeniyle endotel hücre özellikleriyle korelasyonları incelendi. En ince kornea kalınlığı EHY ile zayıf ama anlamlı korele bulundu ( $r=0,231$; $p=0,011)$. Keratokonus tarama indekslerinin tamamına yakını ile DK arasında zayıf ama pozitif yönde anlamlı korelasyon olduğu izlendi $(r=\sim 0.2 ; p<0.05)$. Apikal kurvatür ile DK arasında da anlamlı korelasyon bulunmaktayd $1(r=0.233 ; p=0.01)$. (Tablo 4$)$. 


\section{TARTIŞMA}

Keratokonusun etiyolojisinde bazı genetik mutasyonlar ve çevresel faktörlerin rol oynadığı düşünülmektedir. $\mathrm{Bu}$ faktörlerin ekstrasellüler matriks y1kımı, oksidatif stres ve inflamasyon gibi moleküler değişiklikleri tetiklediği, sonuçta ortaya çıkan histopatolojik değişikliklerin kornea biyomekaniğini etkilediği ve korneayı incelterek keratokonusa neden olduğu ileri sürülmektedir (15). Keratokonusta esas olarak epitel ve stromanın etkilendiği; hastalık ilerledikçe Descement mebranının da etkilenebileceği ama endotelin korunduğu yönünde yayınlar bulunmaktadır (15). Hatta bu yüzden derin anterior lamellar keratoplasti (DALK) cerrahisi keratokonusta penetran keratoplastiye iyi bir alternatif olarak tercih edilmektedir (6). Ancak keratokonusta kornea endotelinde de değişiklikler olduğunu bildiren yayınlar mevcuttur. Mocan ve ark. ile Niederer ve ark. konfokal mikroskopi ile yaptıkları çalışmalarda keratokonuslu gözlerde EHY'nin sağlıklı gözlere göre azaldığını saptamışlardır $(7,8)$. Bununla beraber Hollingsworth ve ark. keratokonuslu gözlerde EHY'nin anlamlı olarak arttığını ileri sürerek aksi yönde sonuçlar bildirmişlerdir (13). Literatürde, keratokonuslu gözlerde sağlıklı gözlere göre EHY'nin anlamlı düzeyde değişmediğini bildiren yayınlar daha fazla sayıdadır (9-12). Bizim çalışmamızda da keratokonusta EHY azalmakla birlikte istatistiksel olarak kontrol grubundan farklı değildi. Çalışmamıza göre keratokonusun anlamlı bir EHY değişikliğine yol açmadığını söyleyebiliriz. Ancak DK açısından keratokonuslu gözlerde anlamlı bir artış mevcuttu. Bu sonuca göre keratokonusta özellikle kornea endotel hücre alan varyasyonunun arttığını söylemek mümkündür. Literatürde sert kontakt lens kullanan keratokonus olgularında polimegatizm ve pleomorfizmin arttığını bildiren yayınlar mevcuttur $(11,16)$. Bu açıdan kontakt lens kullanımının sonuçlarımızı etkilememesi için çalışmamıza kontakt lens kullanan olgular dahil edilmeyerek kontakt lensten bağımsız olarak keratokonus grubunda DK'nın arttığ saptanmıştır.

Keratokonus evreleri arasında EHY'yi karşılaştıran çalışmalarda Uçakhan ve ark. ileri evre gözlerde EHY'nin anlamlı olarak azaldığını bildirmişlerdir. ElAgha ve ark.'nın 40 keratokonuslu gözde speküler mikroskop ile endotel özelliklerini incelediği çalışmada Amsler-Krumeich sinıflamasina göre 3 evre arasında EHY, DK ve H açısından anlamlı fark olmamakla birlikte evre 3 gözlerde EHY ve AHY'nin azaldığ1, DK'nın arttığı bildirilmiştir. Niederer ve ark. ile Timuçin ve ark. CLEK sınıflamasına göre hafif, orta ve ileri evre gözler arasında EHY açısından anlamlı fark olmadığını saptamışlardır. Bozkurt ve ark.'nın speküler mikroskop ile keratokonuslu gözlerde endotel hücre özelliklerini inceledikleri geniş serilerinde hastalık evreleri arasında EHY açısından anlamlı fark olduğu; ileri evre gözlerde EHY'nin azaldığı bildirilmiştir. Polimegatizm ve pleomorfizm açısından hem CLEK sınıflaması hem de pakimetrik sınıflama açısından evreler arasında anlamlı fark saptanmamıştır. Bizim çalışmamızda keratokonus evresi ilerledikçe ortalama EHY ve AHY değerleri sayısal olarak azalmış, DK artmıştır ancak; keratokonus evreleri arasında endotel hücre özellikleri açısından istatistiksel anlamlı fark saptanmamıştır.

Korneal topografi cihazları özgün ektazi indeksleri ile hastalık tanısı, progresyonu ve sınıflaması hakkında yol gösterici olabilmektedir (4). Çalışmamızda Sirius cihazının keratokonus tarama indeksleri açısından keratokonuslu gözlerle kontrol grubu arasında beklendiği üzere anlamlı fark saptandı. Ayrıca, bu indeksler keratokonus evreleri arasında da anlamlı olarak farklıydı. Anlamlılık KVf, KVb ve BCV indeksleri için hem hafif ile orta evre gözler arasında, hem de hafif ve ileri evre gözler arasındaki farktan kaynaklanmaktayd. SIf ve SIb, BCVf ve BCVb indeksleri için sadece hafif ve orta evredeki gözler arasındaki fark anlamlıydı. En ince kornea kalınlığı tüm evreler arasında anlamlı olarak farklı idi. Apikal 
kurvatür de keratokonus evreleri arasında anlamlı olarak farklıyd1; bu farkl1lık hem hafif ile orta evre gözler arasında, hem de hafif ile ileri evre gözler arasındaki farktan kaynaklanmaktaydı. Apikal kurvatür ile $\mathrm{KVf}, \mathrm{KVb}$ ve $\mathrm{BCV}$ indeksleri hastalık evresi ilerledikçe artmakta; en ince kornea kalınlığı ise hastalık evresiyle beraber azalmakta idi. Çalışmamızda keratokonuslu gözleri hastalık şiddetine göre gruplara ayırdığımızda gruplar arasında anlamlı fark saptanan keratokonus tarama indeksleri ile endotel hücre özellikleri arasındaki korelasyonu araştırdık. Bildiğimiz kadarıyla literatürde keratokonusta topografik indeksler ile endotel hücre özellikleri arasında korelasyonu inceleyen 2 çalışma bulunmaktadir $(5,16)$. Goebels ve ark. Pentacam HR (Oculus Optikgerate GmbH, Wetzlar, Almanya) cihazı ile yaptıkları çalışmada topografik keratokonus indeksi (KI) ve yüzey varyans indeksi (ISV) ile speküler mikroskop ile ölçülen endotel hücre alanı, hücre alanı standart deviasyonu, DK, EHY gibi endotel hücre özellikleri arasında anlamlı korelasyon olduğu bildirilmişlerdir. $\mathrm{Bu}$ çalışmada hastalık şiddeti ile endotel hücre büyüklüğü, standart deviasyon ve DK'nın arttığı, EHY'nin ise azaldığı bildirilmiştirdir (16). Bozkurt ve ark. çalışmamızdaki ile aynı marka topografi cihazı kullanarak keratokonuslu gözlerden elde ettikleri EİKK ve apeks pakimetri değerleri ile EHY arasında zayıf ama anlamlı pozitif korelasyon olduğunu; dik ve düz meridyendeki keratometri, ön ve arka elevasyon değerleri (KVf ve $\mathrm{KVb}$ ) ile EHY arasında zayıf ama anlamlı negatif korelasyon olduğunu saptamışlardır. Bizim çalışmamızda da EHY ve EİKK anlamlı derecede korele bulundu. Ancak EHY ile diğer keratokonus tarama indeksleri arasında anlamlı korelasyon saptanmadı. Sonuçlarımıza göre kornea kalınlığı inceldikçe EHY'de azalma olabileceğini söylemek mümkündür. Çalışmamızda DK açısından keratokonuslu gözlerde kontrol grubuna göre anlamlı artış saptanmış, ayrıca DK ile topografik indeksler arasında anlamlı korelasyon olduğu izlenmiştir.

Önceki yayınlardan farklı olarak çalışmamızda Sirius cihazının keratokonus tarama indeksi olarak kullandığ tüm parametreler analize dahil edilmiştir. Hastalık şiddeti konusunda önemli bilgi verebilen bu indeksler ile endotel hücre özellikleri arasında ilişki olduğu saptanmıştır. Keratokonus hastalarının takibinde kornea kalınlığı inceldikçe EHY'nin azaldığı ve hastalık şiddeti ile hücre alan varyasyonunun artabileceği göz önünde bulundurulmalıdır.

Sonuç olarak keratokonusta endotel hücre alan varyasyonunun arttığını; bu artışın topografik keratokonus tarama indeksleri ve apikal kurvatür değerleri ile korele olduğunu ve kornea kalınlığının incelmesiyle EHY'nin azaldığını söylemek mümkündür. Keratokonus hastalarının takibinde kornea endotel hücre özelliklerinin hastalık şiddeti ile beraber değişebildiği göz önünde bulundurulmalıdır.

Çıkar Çatışması: Çalışmamızda çıkar çatışması bulunmamaktadır.

\section{KAYNAKLAR}

1. Feder RS, Gan TJ. Non inflammatory ectatic disorders. In: Krachmer JH, Mannis MJ, Holland EJ, eds. Cornea Fundamentals, Diagnosis and Management. 3rd ed. China. Mosby Elsevier, 2011:865-78.

2. Burcu A. Keratokonus Tedavisinde Güncel Girişimsel Yöntemler. Turk J Ophthalmol. 2013;43(4):263-9.

3. Bilgihan K, Yeşilırmak N. Keratokonus Hastasına Güncel Yaklaşım. MN Oftalmoloji. 2017;24(Suppl 1):54-61.

4. Shetty R, Rao H, Khamar P, Sainani K, Vunnava K, Jayadev $\mathrm{C}$ et al. Keratoconus screening indices and their diagnostic ability to distinguish normal from ectatic corneas. Am J Ophthalmol. 2017;181:140-8. 
5. Bozkurt B, Yılmaz M, Meşen A, Kamış Ü, EkinciKöktekir B, Okudan S. Correlation of corneal endothelial cell density with corneal tomographic parameters in eyes with keratoconus. Turk J Ophthalmol. 2017;47(5):255-60.

6. El-Agha MS, El Sayed YM, Harhara RM, Essam HM. Correlation of corneal endothelial changes with different stages of keratoconus. Cornea. 2014;33(7):707-11.

7. Mocan MC, Yilmaz PT, Irkec M, Orhan M. In vivo confocal microscopy for the evaluation of corneal microstructure in keratoconus. Curr Eye Res. 2008;33(11):933-9.

8. Niederer RL, Perumal D, Sherwin T, McGhee CN. Laser scanning in vivo confocal microscopy reveals reduced innervation and reduction in cell density in all layers of the keratoconic cornea. Invest Ophthalmol Vis Sci. 2008;49(7):2964-70.

9. Uçakhan OO, Kanpolat A, Ylmaz N, Ozkan M. In vivo confocal microscopy findings in keratoconus. Eye Contact Lens. 2006;32(4):183-91.

10. Weed KH, MacEwen CJ, Cox A, McGhee CN. Quantitative analysis of corneal microstructure in keratoconus utilising in vivo confocal microscopy. Eye (Lond). 2007;21(5):614-23.

11. Yeniad B, Yilmaz S, Bilgin LK. Evaluation of the microstructure of cornea by in vivo confocal microscopy in contact lens wearing and non-contact lens wearing keratoconus patients. Cont Lens Anterior Eye. 2010;33(4):167-70.

12. Timucin OB, Karadag MF, Cinal A, Asker M, Asker S, Timucin D. Assessment of corneal endothelial cell density in patients with keratoconus not using contact lenses. Cont Lens Anterior Eye. 2013;36(2):80-5.

13. Hollingsworth JG, Efron N, Tullo AB. In vivo corneal confocal microscopy in keratoconus. Ophthalmic Physiol Opt. 2005;25(3):254-60.
14. Utine CA. Speküler mikroskopi ve konfokal mikroskopi çalışma mekanizmaları ve oftalmolojideki uygulamaları. Türkiye Klinikleri J Ophthalmol. 2011;20(2):89-98.

15. Khaled ML, Helwa I, Drewry M, Seremwe M, Estes A, Liu Y. Molecular and histopathological changes associated with keratoconus. Biomed Res Int. 2017;2017:7803029 (Epub 2017 Jan 30).

16. Goebels S, Eppig T, Seitz B, Szentmàry N, Cayless A, Langenbucher A. Endothelial alterations in 712 keratoconus patients. Acta Ophthalmol. 2018;96(2):e134-e139. 